\title{
DIGITALCOMMONS
}

—@WAYNESTATE-

Wayne State University

$11-1-2005$

\section{Plumage convergence in Picoides woodpeckers based on a molecular phylogeny, with emphasis on convergence in downy and hairy woodpeckers}

Amy C. Weibel

Wayne State University, acweibel@msn.com

William S. Moore

Wayne State University,wmoore1415@gmail.com

\section{Recommended Citation}

Weibel, A. C. and Moore, W. S. 2005. Plumage convergence in Picoides woodpeckers based on a molecular phylogeny, with emphasis on convergence in downy and hairy woodpeckers. Condor 107(4):797-809. http://dx.doi.org/10.1650/7858.1

Available at: http://digitalcommons.wayne.edu/biosci_frp/11 


\title{
PLUMAGE CONVERGENCE IN PICOIDES WOODPECKERS BASED ON A MOLECULAR PHYLOGENY, WITH EMPHASIS ON CONVERGENCE IN DOWNY AND HAIRY WOODPECKERS
}

\author{
Amy C. Weibel ${ }^{1}$ and William S. Moore \\ Department of Biological Sciences, Wayne State University, Detroit, MI 48202
}

\begin{abstract}
Adult and juvenile plumage characters were traced onto a well-resolved molecular based phylogeny for Picoides woodpeckers, and a simple phylogenetic test of homology, parallelism, and convergence of plumage characters was performed. Reconstruction of ancestral character states revealed multiple events of independent evolution of derived character states in most characters studied, and a concentrated changes test revealed that some plumage characters evolved in association with habitat type. For example, there was a statistically significant association between loss of dorsal barring and use of densely vegetated habitats among Picoides species. Two analyses indicated that convergence, as opposed to parallel evolution or shared ancestry, underlies the similarity in plumage patterns between the Downy (Picoides pubescens) and Hairy (P. villosus) Woodpeckers. Possible causal explanations for convergence in plumage patterns may include mimicry and interspecific territoriality.
\end{abstract}

Key words: adaptation, character evolution, convergence, Picoides, plumage, woodpeckers.

Convergencia en Plumaje en Pájaros Carpinteros del Género Picoides Basada en una Filogenia Molecular, con Énfasis en la Convergéncia entre Picoides pubescens y P. villosus

Resumen. Se reconstruyó la evolución de caracteres del plumaje de individuos adultos y juveniles con base en una filogenia molecular bien resuelta de los pájaros carpinteros del género Picoides. El estudio provee una prueba filogenética sencilla de homología, paralelismo y convergencia para los caracteres de plumaje. Las reconstrucciones de estados de caracter ancestrales revelaron múltiples eventos de evolución independiente de estados de caracter derivados en casi todos los caracteres estudiados, y una prueba de cambios concentrados reveló que algunos caracteres del plumaje evolucionaron en asociación con el tipo de hábitat. Por ejemplo, existe una asociación estadísticamente significativa entre la pérdida de barras dorsales y el uso de ambientes con vegetación densa en las especies de Picoides. Dos análisis indicaron que la similitud en los patrones de plumaje entre Picoides pubescens y $P$. villosus puede explicarse por convergencia, no por evolución paralela o por ancestría común. Se discuten posibles explicaciones causales para la convergencia, como la imitación y la territorialidad interespecífica.

\section{INTRODUCTION}

The comparative method is a general and powerful approach for testing hypotheses of adaptation (Ridley 1983) and identifying evolutionary trends (Ridley 1983, Harvey and Pagel 1991) across a range of taxonomic groups. Character states may be maintained in descendent lineages and persist in extant sister species because of shared ancestry (Wilson 1975, Harvey and Mace 1982, McKitrick 1993) or may evolve independently in response to similar selective

Manuscript received 19 April 2005; accepted $10 \mathrm{Au}$ gust 2005 .

${ }^{1}$ Present address: Academic Affairs, Grand Canyon University, Phoenix, AZ 85017. E-mail: acweibel@ msn.com forces in species that experience similar environments (Bell 1989, Harvey and Pagel 1991, Nee et al. 1996). Independent evolutionary events can be identified from a well-resolved phylogeny of the group of taxa under investigation (Pagel and Harvey 1988, Losos 1990, Brooks and McLennan 1991, Omland 1999) and analyzed using the comparative method.

Phenotypic resemblance among species may result from homology, parallel evolution, or convergence. Homology of characters implies structural resemblance due to shared ancestry (Boyden 1973, Patterson 1982). In a review of historical concepts and definitions of homology, Patterson (1982) noted that true homologies are synapomorphies, and thus the test for homology of similar character states is also a test of con- 
gruence within a monophyletic group. Similar character states resulting from parallel or convergent evolution are homoplasies and, collectively, are distinguished from homologies by incongruence with other character states that define a monophyletic group. Parallel and convergent evolution are more difficult to distinguish from each other. Parallel evolution implies structural resemblance in derived character states among closely related species in which developmental pathways were similarly yet independently modified after separation of evolutionary lineages from a common ancestor, whereas convergence in phenotypes results from modification of different antecedent characters or different developmental pathways in distantly related species (Futuyma 1998). Thus, the subtle distinction between parallel and convergent evolution is linked to development as well as phylogeny, and inferences that distinguish the two can be made by studying developmental pathways that transform juvenile to adult character states in a phylogenetic context.

In this study we used MacClade (Maddison and Maddison 1992) to examine plumage character data of Picoides woodpeckers in the context of a well-resolved, DNA-sequence-based phylogeny. Characters are traced or mapped onto a phylogeny using the criterion of maximum parsimony; character state transformations are polarized and ancestral character states are inferred. Thus, patterns of character evolution are detected that allow hypotheses regarding the direction of evolution, adaptation, and developmental programs to be tested.

A particularly intriguing example of apparent convergence in plumage characteristics occurs in the Hairy (Picoides villosus) and Downy ( $P$. pubescens) Woodpeckers. These two broadly sympatric species are so similar in plumage that they can be difficult to distinguish in the field without side-by-side comparison, yet they are not closely related (Weibel and Moore 2002a, 2002b). Although each species belongs to a distinct clade, they more closely resemble each other than other members of their respective clades (Fig. 1). Here we test the hypothesis of convergence in plumage characters in Picoides woodpeckers and discuss potential adaptive causes of convergence specifically in Hairy and Downy Woodpeckers.

\section{METHODS}

The phylogeny that served as the comparative framework for this study was estimated from pooled DNA sequences of two mitochondrial protein-coding genes, cytochrome oxidase I $(C O I)$ and cytochrome $b(c y t b)$, and a nuclear gene intron, $\beta$-fibrinogen intron 7 ( $\beta$-fibint 7$)$ (Weibel and Moore 2002b). The phylogeny is the maximum likelihood topology for the data set based on a general time-reversible nucleotide rate variation model that included the proportion of invariable sites and the gamma distribution shape parameter $(G T R+I+\Gamma)$. The portion of the Weibel and Moore (2002b) tree relevant to this study is presented in Figure 2 and 3.

Adult plumage data were collected from study skins housed at the University of Michigan Museum of Natural History. Male and female adult plumages were evaluated using characters and methods following Short (1971). Because of substantial geographic variation in most Picoides species, we selected for study subspecies that were used by Winkler et al. (1995) for species descriptions. Juvenile plumage character data were extracted primarily from Short (1971, 1982), Ehrlich et al. (1988), and Winkler et al. (1995). Data were arranged into two matrices (adult plumage and juvenile plumage). Characters were individually traced onto the 3-gene species tree using the criterion of simple parsimony (unordered parsimony) in MacClade, version 3.0 (Maddison and Maddison 1992), in which gains and losses are given equal probabilities and ancestral states are reconstructed based on character states of extant lineages. The phylogeny is rooted (Weibel and Moore 2002a, $2002 \mathrm{~b}$ ), thus character states are polarized allowing inference of ancestral versus derived states in the Picoides clade.

Levels of similarity in plumage patterns among species pairs were evaluated, and the total number of character states (ancestral + derived) held in common for all pairwise species comparisons in each of the two plumage matrices were tabulated. The empirical distributions of total character states held in common between pairs of species were represented in histograms for adult and juvenile plumage data using NCSS 2000 statistical software (Hintze 1999). Pairs of species for which high overall resemblance in adult plumage is outwardly apparent were located on the histograms. Species pairs with the 
Clade of "small" Picoides
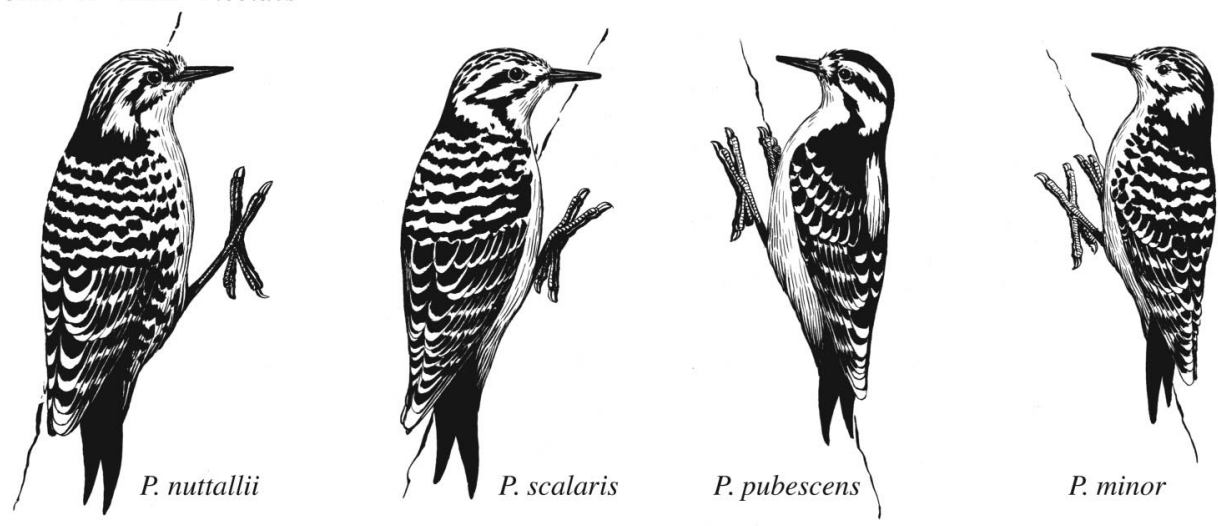

Clade of "large" Picoides
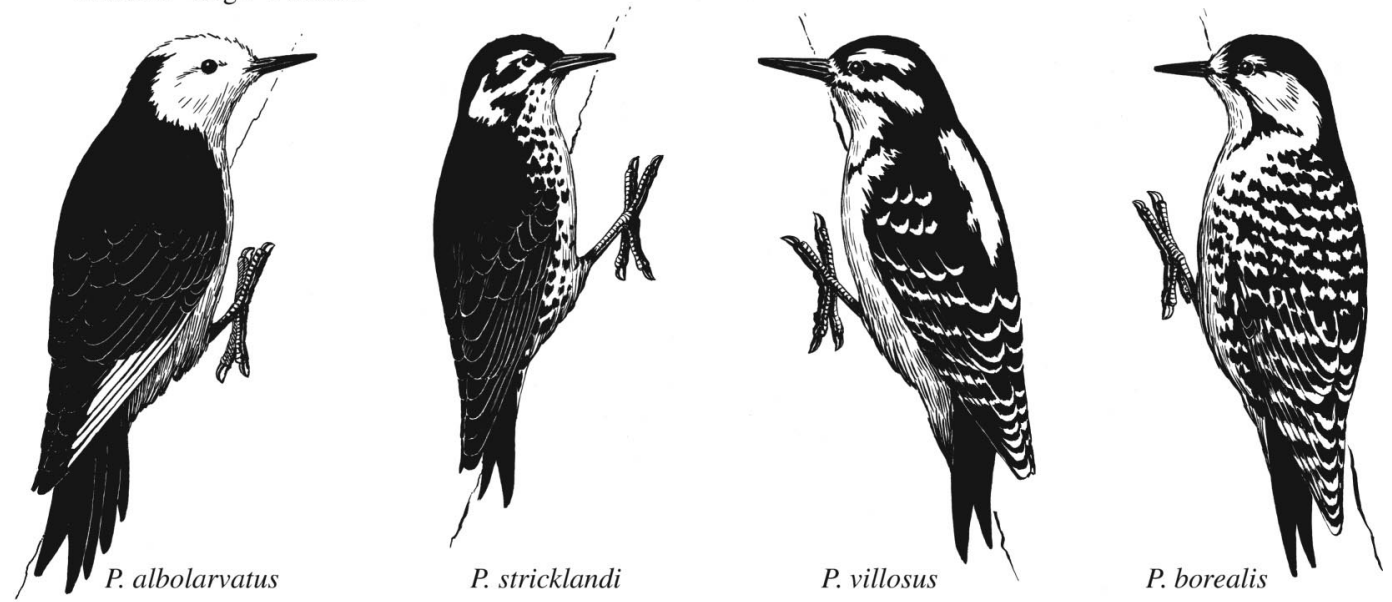

FIGURE 1. Sketches of North American "small” Picoides: P. nuttallii, P. scalaris, P. pubescens, P. minor (a Eurasian species); and "large" Picoides: P. albolarvatus, P. stricklandi, P. villosus, P. borealis. Note the extensive similarity in plumage between the distantly related species, $P$. pubescens and $P$. villosus. Drawings by John Megahan from study skins housed in the University of Michigan Museum of Natural History.

greatest level of plumage similarity are expected to share the greatest number of character states (both ancestral and derived states). Hypotheses of homology, parallelism, and convergence were tested among species pairs having high levels of similarity in adult plumage patterns by comparing the total number of shared adult plumage character states with the total number of shared juvenile plumage character states.

Field observations revealed a trend of decreased dorsal barring or streaking in woodpeckers that utilize dense vegetation rather than open habitat (WSM, unpubl. data). We tested this hypothesis for Picoides by a concentrated changes test (Maddison 1990) in MacClade. The analysis tests the null hypothesis that changes in a binary dependent character (in this case, dense versus open habitat) are randomly distributed in a defined clade regardless of the state of another independent character (in this case, barred versus solid back, mantle, or wing patterning). Assignment of characters in this way stems from the logic that phenotypic characters arise independent of environment, and those characters that allow an individual to exploit some component of the environment are favored by selection (Westneat 1995). A probability distribution for gains and losses of the dependent character is generated by simulation. An independent character is traced onto the phylogenetic framework, and significant evolutionary association between dependent and independent character 
states is determined from the null probability distribution using the observed number of gains and losses of the dependent character state in lineages having a specified independent character state.

\section{RESULTS}

Plumage characters and character states (ancestral vs. derived) are listed in the Appendix, with species grouped according to phylogenetic relationships based on Weibel and Moore (2002b). Data for species of a given clade are represented with a unique letter $(A-G)$ such that character states in the context of phylogenetic relationships can be readily identified. Intraspecific variation occurred in all characters studied, thus character state assignments are likely simplistic and not descriptive of a species as a whole. However, character state assignments do reflect the general phenotype of a given species (Westneat 1995). The derived character state evolved multiple times independently in all characters studied; i.e., homoplasy is high in adult plumage characters. Ancestral character states for some characters are not resolved; these equivocal states are noted in the Appendix.

Reversals to the ancestral condition occurred in two characters: crown (character 2; Appendix,
Fig. 2) and mantle (character 7; Appendix, Fig. $3 b)$ patterning. There is an overall loss of head patterning in Picoides species as shown by the evolutionary reduction of a distinct malar patch (character 1), the narrowing of the auricular patch (character 5), the reduced expression of male ornamentation (character 10), and the transformation from distinct white nasal tufts (character 13) to black or indistinct dusky nasal tufts (Appendix). Overall body patterning in $\mathrm{Pi}$ coides has also decreased over evolutionary time: barring on the outer retrices (character 3; Appendix), back (character 6; Appendix, Fig. 3a), and wing (character 9; Appendix, Fig. 3c) are ancestral states, as is ventral speckling (character 8; Appendix). However, ventral barring (character 8) has only recently evolved in $\mathrm{Ve}$ niliornis (Appendix), and barring is derived in Picoides in some less conspicuous characters: inner retrices (character 4; Appendix, Fig. 4), mantle (character 7; Appendix, Fig. 3b) and throat (character 12; Appendix) patterning. Thus, adult plumage of the common ancestor to Picoides was likely dorsally barred or spotted with speckled ventral patterning and well-developed head markings but with no markings on the throat. Male ornamentation was expressed on the crown with no streaking or spotting.

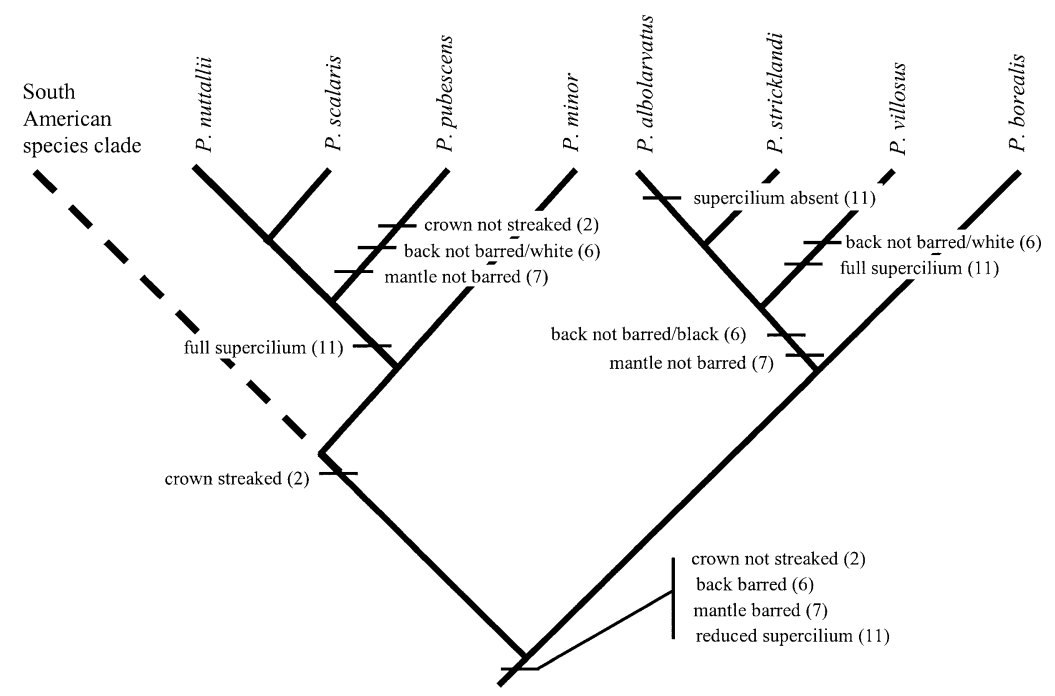

FIGURE 2. Relevant portion of the phylogenetic tree showing rejection of homology for four characters held in common between $P$. pubescens and $P$. villosus. Plumage similarity between these two species results from evolutionary reversals in two characters (crown streaking and mantle barring) and independent evolution of a full supercilium and loss of back barring. Characters are numbered according to their listing in the Appendix. Ancestral characters states are inferred from the species tree of all Picoides species studied thus far (Weibel and Moore 2002a, 2002b). 


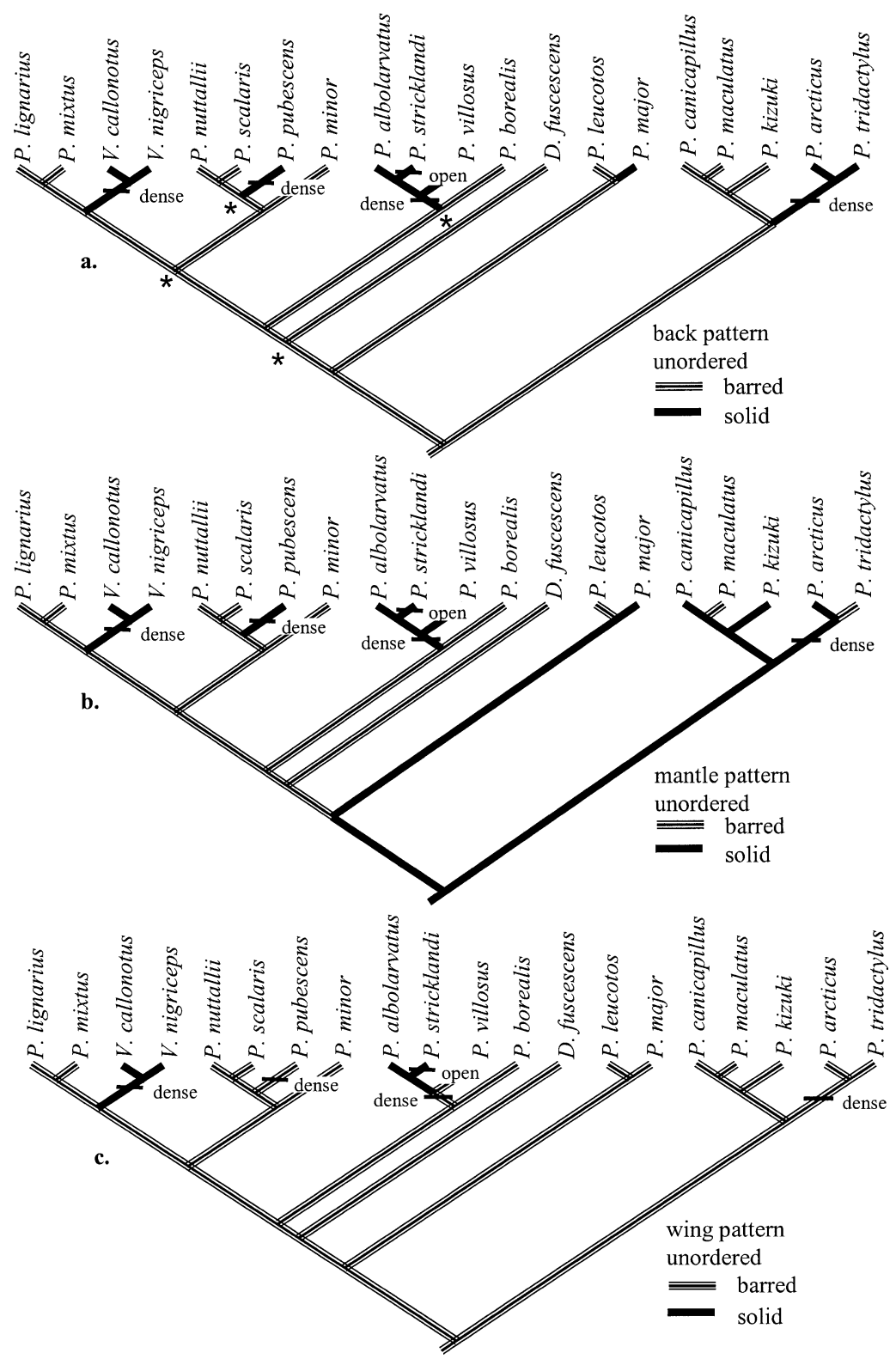

FIGURE 3. Reconstruction of ancestral character state based on a simple parsimony criterion for plumage characters in Picoides woodpeckers: (a) back pattern, (b) mantle pattern, and (c) wing pattern of a folded wing. Species utilization of open versus dense habitat is mapped on the phylogeny. An asterisk is used in (a) to identify those nodes supported by bootstrap values that are between $50 \%$ and $70 \%$.

Little is described or known about juvenile plumage patterns. Of the six characters studied, four show evidence of multiple independent evolution of the derived state (Appendix). Crown streaking (character 2) may have arisen three times, and strong sexual dimorphism (character 3) in chicks evolved at least twice with two possible reversals to the ancestral state. Diffuse ventral patterning (character 5) may have evolved independently several times, but the precise number of events is difficult to assess because of unresolved transformations in several 


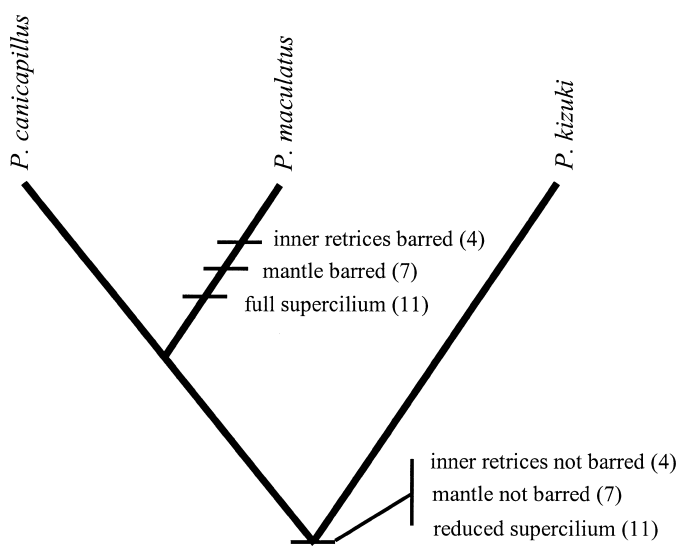

FIGURE 4. Relevant part of the phylogenetic tree showing rejection of homology for three characters held in common between P. canicapillus and P. kizuki. Plumage similarity between these two species results from shared ancestral character states of reduced supercilium and lack of barring in inner retrices and mantle; no perceptible evolution has occurred in these characters. Characters are numbered according to their listing in the Appendix. Ancestral characters states are inferred from the species tree of all Picoides species studied thus far (Weibel and Moore 2002a, 2002b).

ancestral lineages of the genus. However, it is clear that ventral speckling in chicks, regardless of pattern intensity, is found in all species of Picoides studied thus far. Juvenile plumage in the common ancestor to Picoides may have been expressed as unstreaked crown coloration with subtle or no sexual dimorphism; both female and male chicks display adult male head ornamentation. The overall patterning of juveniles was likely similar to adults, but with duller dorsal coloration and heavier ventral patterning.

Dense habitat use evolved at least four times in the Picoides phylogeny (Fig. 3), with one loss (or reversal to open habitat use) in the P. stricklandi lineage. The probability that an observed number of gains (and losses) of dense habitat use also occurred in lineages of woodpeckers having a certain character state was calculated with a concentrated changes test by comparing the tracing of dense habitat use in the phylogeny with the tracing of the character state. For example, dense habitat use was gained along four lineages having solid back patterning and was lost in one lineage with solid patterning (Fig. 3a). Thus, the probability of observing four gains and one loss of dense habitat use in lineages of woodpeckers with solid back patterning by random chance is 0.003 . Significant evolutionary associations (Table 1) were detected between dense vegetation and solid back patterning (Fig. 3a), solid mantle patterning (Fig. 3b), and solid wing patterning (Fig. 3c).

Histograms from all $(n=190)$ pairwise species comparisons for number of shared character states in adult and juvenile plumages are shown in Figure 5. In general, all Picoides species have similar black and white plumage patterns with variable barring, streaking, or spotting (Fig. 1). Each of the species pairs was mapped onto the distribution of shared adult plumage characters (Fig. 5a) and shared juvenile plumage characters (Fig. 5b). Three species pairs with visibly similar adult plumage characteristics fall in the extreme tail of the empirical distribution. Species pairs with the most similar adult plumage patterns are $P$. lignarius $-P$. mixtus (A) from South America (13 of 13 characters), P. pubescens $-P$. villosus (B) from North America (12 of 13 characters), and P. canicapillus-P. kizuki (C) from Asia (11 of 13 characters). Two other species pairs sharing 11 of 13 character states ( $P$. scalaris-P. minor and Dendropicos fuscescens $-P$. maculatus) are not visibly similar in appearance though their character states are the same for most characters. For example, the absence of an auricular patch on $P$. minor clearly distinguishes the species from $P$. scalaris, and $D$. fuscescens

TABLE 1. Concentrated changes of observed character associations in Picoides woodpeckers. Decimal values are probabilities that evolutionary association of characters occur other than by random chance. Bold probabilities coincide with the observed loss of dense vegetation use and gains in this type of habitat use in lineages having solid back, mantle, or wing patterning based on Figure 3.

\begin{tabular}{llcccccc}
\hline \hline \multirow{2}{*}{$\begin{array}{c}\text { Independent } \\
\text { character-traced }\end{array}$} & \multicolumn{2}{c}{ Observed } & \multicolumn{5}{c}{ Gains } \\
\cline { 5 - 8 } & Dependent character & losses & 0 & 1 & 2 & 3 & 4 \\
\hline Back pattern (solid) & Habitat (dense vegetation) & 1 & 0.040 & 0.154 & 0.152 & 0.045 & $\mathbf{0 . 0 0 3}$ \\
Mantle pattern (solid) & Habitat (dense vegetation) & 1 & 0.014 & 0.127 & 0.255 & 0.135 & $\mathbf{0 . 0 1 6}$ \\
Wing pattern (solid) & Habitat (dense vegetation) & 1 & 0.094 & 0.101 & $\mathbf{0 . 0 2 4}$ & 0.001 & 0.000 \\
\hline
\end{tabular}



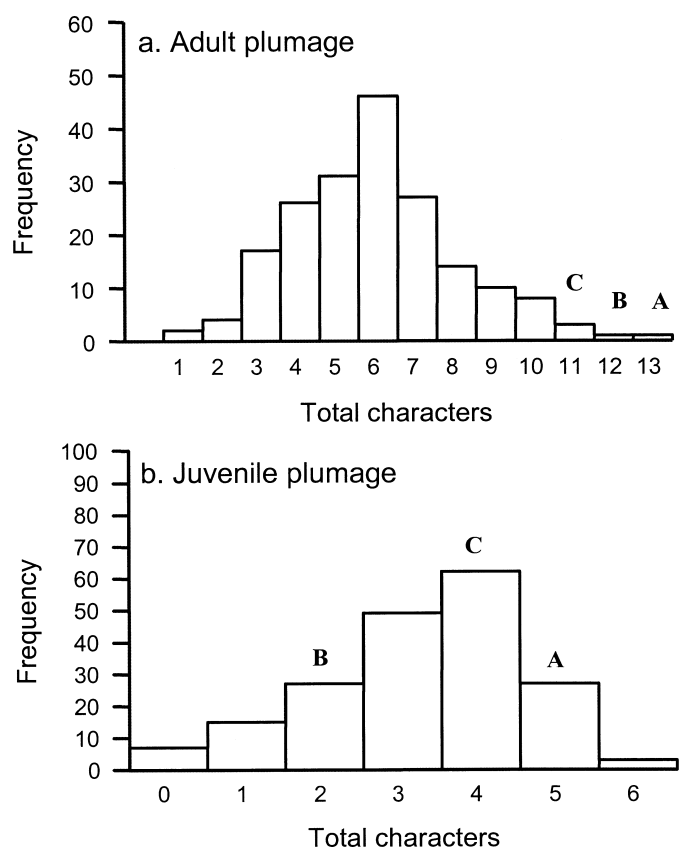

FIGURE 5. Histograms of all pairwise species comparisons $(n=190)$ for the number of character states held in common for (a) adult plumage characters and (b) juvenile plumage characters. Picoides species pairs with the most similar plumages are identified on histograms by upper case letters: $\mathrm{A}=P$. lignarius $-P$. mixtus, $\mathrm{B}=P$. pubescens $-P$. villosus, and $\mathrm{C}=P$. canicapillus-P. kizuki.

has greenish rather than black and white plumage (Winkler et al. 1995). Of the three species pairs with the most similar adult plumage pattern, the $P$. lignarius $-P$. mixtus pair shares five of six juvenile plumage character states (Fig. 5b); the $P$. canicapillus $-P$. kizuki pair has four of six juvenile plumage character states in common and the $P$. pubescens $-P$. villosus pair shares only two of six juvenile plumage character states.

\section{DISCUSSION}

Earlier studies of plumage character evolution in Picoides woodpeckers (Bock 1963, Short 1971, 1974) relied on plumage, behavioral, ecological, and external morphological characters to reconstruct phylogeny. Bock (1963) and Short (1971) suggested that plumage characters are particularly useful in systematic studies of groups such as woodpeckers, in which specialized features have limited morphological variation. However, plumage and other phenotypic character data in- troduce a suite of problems for correctly reconstructing evolutionary relationships, as characters may not evolve independently and their genetic basis is poorly understood (Hillis 1987). The plumage patterns used by Short (1971) and examined here are clearly subject to evolutionary convergence and reversal (Christidis et al. 1988, Omland and Lanyon 2000). Furthermore, plumage patterns that are sexually selected (Burns 1998) may be driven by genetic expression but may also be influenced by hormonal changes or environmentally induced developmental changes. Thus, plumage characters are considered highly labile and of dubious value for phylogenetic analysis (Christidis et al. 1988, Hackett and Rosenberg 1990, Kusmierski et al. 1997, Omland and Lanyon 2000, but see Livezey 1991, Prum 1997, Chu 1998). Perhaps the greatest difficulty with Short's (1971) evaluation of character evolution in Picoides woodpeckers is the lack of independence between the character data under study and the data used to reconstruct the phylogenetic framework.

The veracity of ancestral character state reconstructions based on comparative studies depends on the accuracy of the phylogeny and its correct rooting. The phylogeny used in this study is the maximum likelihood tree reconstructed under the GTR $+\mathrm{I}+\Gamma$ substitution model from a data matrix comprising concatenated DNA sequences, totaling 3451 nucleotides from two mitochondrial genes and a nuclear gene intron. Although the probabilistic meaning of bootstrap support values is debated, they underestimate true probabilities that nodes are real when the bootstrap support value is greater than 50\% (Felsenstein and Kishino 1993). As a rough approximation, bootstrap values of $70 \%$ are interpreted as $95 \%$ certainty that nodes are real (Hillis and Bull 1993). For the tree used in this study, 15 of 19 nodes have bootstrap values greater than $70 \%$, and the remaining four nodes have values between $54 \%$ and $70 \%$. Because the tree we used is based on maximum likelihood using a realistic substitution model and a large nucleotide sample, and because bootstrap support is generally strong, we believe the topology used for our comparative analysis is substantially correct.

The tree depicted in Figure 3 is rooted at the common ancestor of Picoides as determined by outgroup analysis (Weibel and Moore 2002b). A potential concern is some uncertainty as to 
which group of genera is sister to Picoides, the clade comprising the genera Melanerpes and Sphyrapicus or a clade including Colaptes, Piculus, and Dryocopus (Moore et al. 2005). The Colaptes clade is the sister clade to Picoides in the 3-gene tree we used as our comparative framework, and this relationship persists when only $c y t b$ and $C O I$ sequences are used in phylogenetic analysis (Weibel and Moore 2002a). However, phylogenetic analyses which included the mitochondrial $12 S$ rRNA gene in addition to cyt $b$ and COI (Webb and Moore 2005) and those using only $\beta$-fibint7 sequences (Weibel and Moore 2002b) infer the Melanerpes clade as the sister clade to Picoides. However, this concern is obviated here by the fact that in all cases the basal split in Picoides is the same as depicted in Figure 3, and thus this uncertainty should not affect our analysis.

Polarization of character state changes in this study was based on rooting the Picoides part of the tree with the DNA-based phylogeny and not with a phylogeny based on the plumage characters, i.e., mapping the most parsimonious distribution of plumage character state changes on the tree was independent of the process of constructing the tree. Moreover, our reconstruction of ancestral character states depended only on the distribution of character states among species within Picoides and not on more distant outgroups where homology of character states becomes more dubious.

Tracing the most parsimonious character state transitions on the phylogeny revealed several interesting patterns of convergence, parallelism, and retention of ancestral plumage states, which most plausibly result from ecological selection, sexual selection, or social selection. In particular, the overall loss of head patterning and dorsal barring or streaking strongly suggests that these suites of characters have been influenced by selection, though identifying the selective agent driving these evolutionary patterns is difficult. Correlation in the evolution of a physical character and an ecological character narrows the field of potential selective agents to examine, such as the correlation between lack of dorsal barring and use of dense habitat in Picoides. However, a simple adaptive interpretation of the relationship between plumage and habitat could be complicated by sexual selection or the role of plumage in territorial defense. For example, Johnson and Lanyon (2000) determined that the evolution of carotenoid plumage and epaulets were associated with marsh nesting in a group of blackbirds. They suggested these plumage characteristics are adaptive because of increased sexual selection in variable marsh territories or greater male-male interactions due to increased density of territories in marshes. To reject these or other evolutionary hypotheses, comparative studies of the relationships of various characters and habitats of many different species would be required (Johnson and Lanyon 2000). Thus, while the correlations between plumage and habitat components detected in Picoides suggest an important evolutionary pattern in niche partitioning, more comparative and experimental studies are necessary to understand how evolutionary forces gave rise to specific plumage traits, and how these traits are related to ecology.

Phylogenetic tests of homology were applied to adult plumage character data to identify plausible evolutionary explanations for high plumage resemblance in three pairs of Picoides species: $P$. lignarius $-P$. mixtus, $P$. canicapillus $-P$. kizuki, and $P$. pubescens- $P$. villosus. Much like the approach of cladistic compatibility (Meacham and Estabrook 1985), character states are inferred to be homologous if they support a monophyletic group specified by other homologous characters; i.e., the test rejects evolutionary homology if character states are not synapomorphies for a specific clade. All character states shared between $P$. lignarius and $P$. mixtus pass this test, thus their plumage resemblance is attributable to shared ancestry (homology). This is consistent with the DNA-based phylogenetic inference that they are closely related sister species.

However, homology is rejected for several character states held in common by $P$. canicapillus and $P$. kizuki and by $P$. pubescens and $P$. villosus. Reconstruction of phylogeny based on these characters would be incongruent with the Picoides species tree (Weibel and Moore 2002a, $2002 b)$. Note that though they are not sister species, the similarity in adult plumage between $P$. canicapillus and P. kizuki is attributable to homology in the form of retention of shared ancestral character states (sympleisiomorphies), whereas $P$. maculatus, the sister species to $P$. canicapillus, has three autapomorphic character states. Thus, no perceptible evolutionary changes have occurred in the plumage characters examined here. $P$. pubescens and $P$. villosus, in 
contrast, share most adult plumage character states but differ substantially in juvenile plumage. Thus, the patterns of adult and juvenile plumage in these two species in the context of the phylogeny are most consistent with the hypothesis of convergent evolution of adult plumage. Perhaps the most compelling reason for rejecting evolutionary homology (shared ancestry) as an explanation of plumage similarity between $P$. pubescens and $P$. villosus is that these species are phylogenetically arranged into two different clades in which the most recent common ancestor of the pair unites all New World Picoides species.

Given that the plumage similarity of $P$. villosus and $P$. pubescens (hereafter Hairy and Downy Woodpeckers, respectively) is not the result of homology, it is of interest to infer whether it results from parallel or convergent evolution. Usually parallel evolution occurs in relatively closely related species, whereas convergence occurs in more distantly related species (Futuyma 1998). Details of specific pathways in the development of juvenile and adult plumage in woodpeckers are lacking, and so these alternative hypotheses cannot be directly tested. However, a weaker, indirect test can be made by comparing levels of similarity between adults and juveniles of the two species in a phylogenetic context. Strong similarity of adult plumage contrasted by strong dissimilarity of juvenile plumage between distantly related species is consistent with the prediction of convergent evolution and inconsistent with the prediction of parallel evolution.

Convergence in characters among species is thought to be a key indicator of adaptation, especially as a response to similar environmental pressures (Patterson 1988). Nevertheless, Wake (1991) argued that there are alternative explanations for phenotypic resemblance, for example similarities may arise by random chance where superficially similar character states between taxa could result from the adaptive process in one species but as a result of modification of the developmental program in the other species (Wake 1991). However, these similar character states, although having evolved by different processes, may then be favored concurrently by selection leading to even greater similarity in characteristics; thus, close similarity ultimately arises by adaptation. However, for Hairy and Downy Woodpeckers, Wake's argument is im- probable because the plumage similarity is highly detailed, involving a large suite of similar characteristics in these two distantly related species.

Several hypotheses have been proposed to explain why distantly related taxa may converge in external appearance. For example flocking species may converge to avoid predation through mimicry (Barnard 1979) and sympatric species may mimic one another to elicit or avoid behavioral interactions (Moynihan 1960, 1968, Diamond 1982). The Downy Woodpecker is a much smaller bird than the Hairy Woodpecker, which is typically the more aggressive species, and convergence may reduce aggressive exchanges between the two species; Hairy Woodpeckers may attack larger rather than smaller competitors (Diamond 1982). However, it is unlikely the Downy Woodpecker is mimicking the Hairy Woodpecker under this hypothesis because neither is considered a flocking species. Convergence may be explained by Müllerian mimicry, with both species converging onto similar features, but it is doubtful that either species harbors toxins or other factors that would be dangerous to predators as their primary predator is likely hawks.

Cody (1969) proposed the hypothesis of interspecific territoriality to explain convergence in avian species, specifically woodpeckers. The model premise is that it is economically advantageous for sympatric competitors to recognize and exclude each other from territories in order to maximize available resources, and the process is facilitated when competitors have similar phenotypes thereby reducing the number of recognition signals to learn. Convergent evolution by interspecific territoriality can only affect characteristics involved in visual or acoustic aggressive displays, but cannot interfere with intersexual recognition. The competitors must be congeners (but not sibling species) and territorial (or at least demonstrate intrasexual aggressive behavior), and similarities are expected to be less pronounced where species are allopatric.

Interspecific territoriality may be the best explanation for convergence between Downy and Hairy Woodpeckers; the hypothesis is supported by phylogenetic analysis (Weibel and Moore 2002a, 2002b) and evaluation of plumage traits presented here. Moreover, it is likely that the two species compete for a common limiting resource, suitable nest-cavity substrate. Hairy and 
Downy Woodpeckers are extensively sympatric across the North American continent, but the distribution of the Downy Woodpecker does not extend into the Southwest or Central America. Further support for the interspecific territoriality hypothesis comes from a plumage variant of the Hairy Woodpecker with brownish rather than white underparts found in Central America (Winkler et al. 1995), a region in which Downy Woodpeckers do not reside. Behavioral studies in the field are required to further substantiate interspecific territoriality as the causal explanation for convergence in Downy and Hairy Woodpeckers.

Many other Picoides species are sympatric with both Downy and Hairy Woodpeckers in parts of their ranges in western and southwestern North America, and most species have vivid black and white plumage patterns. However, these species not only have different ecological requirements, they also have distinguishing plumage characteristics that make identification in the field relatively easy. Thus, the evolutionary processes that mold plumage patterns among Picoides species are likely as diverse as the species themselves. This study provides strong support that the striking resemblance of Hairy and Downy Woodpeckers is the result of convergent evolution, regardless of the underlying selective factors.

\section{ACKNOWLEDGMENTS}

We thank J. Hinshaw for her assistance at the University of Michigan Museum of Natural History and two anonymous reviewers whose comments improved this manuscript. Our special thanks to J. Megahan for his artistic contribution to this paper. This research was supported in part by the William A. Turner, Jr. Memorial Scholarship, Wayne State University Graduate School Thesis/Dissertation Research Support, and two National Science Foundation grants (DEB-9316452 and DEB-9726512) awarded to WSM.

\section{LITERATURE CITED}

BARNARD, C. J. 1979. Predation and the evolution of social mimicry in birds. American Naturalist 13: 613-618.

Bell, G. 1989. A comparative method. American Naturalist 133:553-571.

Bock, W. J. 1963. Evolution and phylogeny in morphologically similar groups. American Naturalist 97:265-285.

Boyden, A. 1973. Perspectives in zoology. Pergamon Press, Oxford.

Brooks, D. R., And D. A. McLennan. 1991. Phylogeny, ecology and behavior: a research program in comparative biology. University of Chicago Press, Chicago.

BuRns, K. J. 1998. Molecular phylogenetics of the genus Piranga: implications for biogeography and the evolution of morphology and behavior. Auk 115:621-634.

Christidis, L., R. Schodde, And P. R. Baverstock. 1988. Genetic and morphological differentiation and phylogeny in the Australo-Papuan scrubwrens (Sericornis, Acanthizidae). Auk 105:616-629.

Chu, P. C. 1998. A phylogeny of the gulls (Aves: Larinae) inferred from osteological and integumentary characters. Cladistics 14:1-43.

Cody, M. L. 1969. Convergent characteristics in sympatric species: a possible relation to interspecific competition and aggression. Condor 71:222-239.

DiAmond, J. M. 1982. Mimicry of friarbirds by orioles. Auk 99:186-196.

Ehrlich, P. R., D. S. Dobkin, AND D. Wheye. 1988. The birder's handbook: a field guide to the natural history of North American birds. Simon and Schuster, New York.

Felsenstein, J., AND H. Kishino. 1993. Is there something wrong with the bootstrap on phylogenies? A reply to Hillis and Bull. Systematic Biology 42: 193-200.

FutuYMA, D. J. 1998. Evolutionary biology. 3rd ed. Sinauer Associates, Sunderland, MA.

Hackett, S. J., And K. V. Rosenberg. 1990. Comparison of phenotypic and genetic differentiation in South American antwrens (Formicariidae). Auk 107:473-489.

Harvey, P. H., And G. M. Mace. 1982. Comparisons between taxa and adaptive trends: problems of methodology, p. 343-361. In King's College Sociobiology Group [EDS.], Current problems in sociobiology. Cambridge University Press, Cambridge, UK.

Harvey, P. H., AND M. D. Pagel. 1991. The comparative method in evolutionary biology. Oxford University Press, Oxford.

HiLlis, D. M. 1987. Molecular versus morphological approaches to systematics. Annual Review of Ecology and Systematics 18:23-42.

Hillis, D. M., AND J. J. Bull. 1993. An empirical test of bootstrapping as a method for assessing confidence in phylogenetic analysis. Systematic Biology 42:182-192.

Hintze, J. L. 1999. NCSS 2000 statistical system for Windows. Kaysville, UT.

JoHnSON, K. P., AND S. M. LANYON. 2000. Evolutionary changes in color patches of blackbirds are associated with marsh nesting. Behavioral Ecology 11: $515-519$.

Kusmiersi, R., G. Borgia, A. Uy, And R. H. Crozier. 1997. Labile evolution of display traits in bowerbirds indicates reduced effects of phylogenetic constraint. Proceedings of the Royal Society of London Series B 264:307-313.

Livezey, B. C. 1991. A phylogenetic analysis and classification of recent dabbling ducks (Tribe Anatini) based on comparative morphology. Auk 108:471507. 
Losos, J. B. 1990. A phylogenetic analysis of character displacement in Caribbean Anolis lizards. Evolution 44:558-569.

Maddison, W. P. 1990. A method for testing the correlated evolution of two binary characters: are gains or losses concentrated on certain branches of a phylogenetic tree? Evolution 44:539-557.

Maddison, W. P., And D. R. Maddison. 1992. MacClade: analysis of phylogeny and character evolution, version 3.0. Sinauer and Associates, Sunderland, MA.

McKitrick, M. C. 1993. Phylogenetic constraint in evolutionary theory: has it any explanatory power? Annual Review of Ecology and Systematics 24:307-330.

Meacham, C. A., and G. F. Estabrook. 1985. Compatibility methods in systematics. Annual Review of Ecology and Systematics 16:431-446.

Moore, W. S., A. C. Weibel, And A. Agius. 2005. Mitochondrial DNA phylogeny of the woodpecker genus Veniliornis (Picidae, Picinae) and related genera implies convergent evolution of plumage patterns. Biological Journal of the Linnean Society, in press.

MoyniHAN, M. 1960. Some adaptations which help to promote gregariousness. Proceedings of the 12th International Ornithological Congress: 523-541.

Moynihan, M. 1968. Social mimicry; character convergence versus character displacement. Evolution 22:315-331.

NeE, S., A. F. Read, And P. H. Harvey. 1996. Why phylogenies are necessary for comparative analysis, p. 399-411. In E. P. Martins [ED.], Phylogenies and the comparative method in animal behavior. Oxford University Press, Oxford.

OMLAND, K. E. 1999. The assumptions and challenges of ancestral state reconstructions. Systematic $\mathrm{Bi}-$ ology 48:604-611.

OMland, K. E., and S. M. LANYON. 2000. Reconstructing plumage evolution in orioles (Icterus): repeated convergence and reversal in patterns. Evolution 54:2119-2133.

Pagel, M. D., and P. H. Harvey. 1988. Recent developments in the analysis of comparative data. Quarterly Review of Biology 63:413-440.

PAtTERSON, C. 1982. Morphological characters and homology, p. 21-74. In K. A. Joysey and A. E. Fri- day [EDS.], Problems of phylogenetic reconstruction. Academic Press, New York.

Patterson, C. 1988. Homology in classical and molecular biology. Molecular Biology and Evolution 5:603-625.

Prum, R. O. 1997. Phylogenetic tests of alternative intersexual selection mechanisms: trait macroevolution in a polygynous clade (Aves: Pipridae). American Naturalist 149:668-692.

RIDLEY, M. 1983. The explanation of organic diversity: the comparative method and adaptations for mating. Clarendon Press, Oxford.

SHORT, L. L. 1971. Systematics and behavior of some North American woodpeckers, genus Picoides (Aves). Bulletin of the American Museum of Natural History 145:1-118.

SHORT, L. L. 1974. The contribution of external morphology to avian classification. Proceedings of the 16th International Ornithological Congress:185195.

SHORT, L. L. 1982. Woodpeckers of the world. Delaware Museum of Natural History, Greenville, DE.

WAKE, D. B. 1991. Homoplasy: the result of natural selection or evidence of design limitations? American Naturalist 138:543-567.

WebB, D. M., AND W. S. Moore. 2005. A phylogenetic analysis of woodpeckers and their allies using $12 S$, cyt $b$ and $C O I$ nucleotide sequences (Class Aves; Order Piciformes). Molecular Phylogenetics and Evolution 36:233-248.

Weibel, A. C., AND W. S. Moore. 2002a. Molecular phylogeny of a group of cosmopolitan woodpeckers (genus Picoides) based on COI and cyt b mitochondrial gene sequences. Molecular Phylogenetics and Evolution 22:65-75.

Weibel, A. C., AND W. S. Moore. 2002b. A test of a mitochondrial gene-based phylogeny of woodpeckers (genus Picoides) using an independent nuclear gene, $\beta$-fibrinogen intron 7. Molecular Phylogenetics and Evolution 22:247-257.

Westneat, M. W. 1995. Feeding, function, and phylogeny: analysis of historical biomechanics in labrid fishes using comparative methods. Systematic Biology 44:361-383.

WILsON, E. O. 1975. Sociobiology. Harvard University Press, Cambridge, MA.

Winkler, H., D. A. Christie, And D. Nurney. 1995. Woodpeckers: an identification guide to the woodpeckers of the world. Houghton Mifflin, Boston, MA. 
APPENDIX. Polarized character states for Picoides in the context of phylogenetic relationships. Picoides species and representative species of Veniliornis and Dendropicos that render Picoides paraphyletic are listed in order according to phylogenetic relationships inferred from the tree in Weibel and Moore (2002b) and shown in Figure 3. Data for species of a given clade are presented with a unique letter $(A-G)$ such that character states

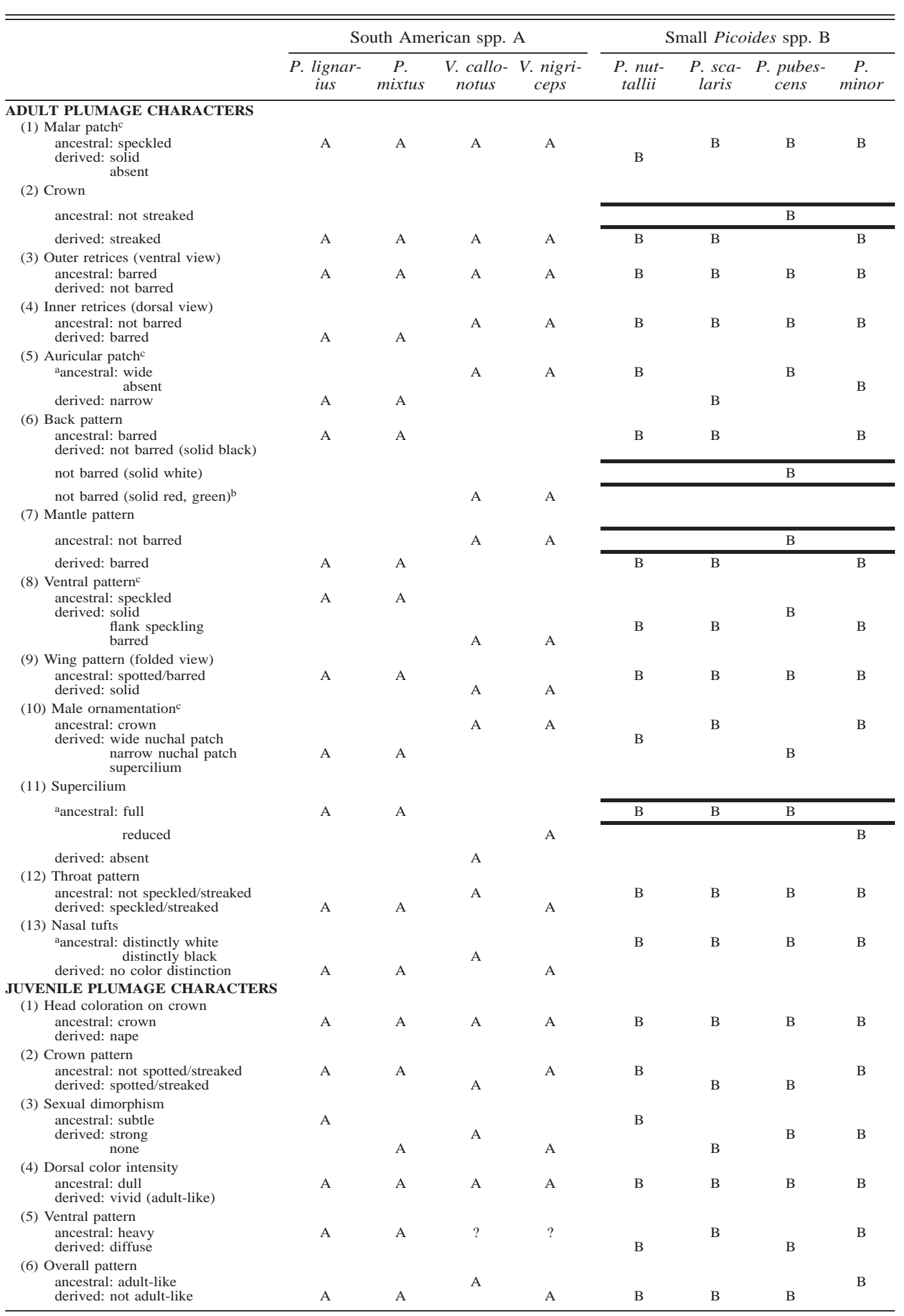

a Estimation of ancestral character states are equivocal.

${ }^{\mathrm{b}}$ Character state for back pattern in $V$. callonotus and $V$. nigriceps is solid red and solid green, respectively. 
APPENDIX. Extended.

in the context of phylogenetic relationships can be readily identified. Character states that are not evolutionarily homologous in $P$. pubescens $-P$. villosus and $P$. canicapillus $-P$. kizuki species pairs (Fig. 2 and 4, respectively) are identified by upper and lower borders, and ancestral character state estimates are fully resolved.

\begin{tabular}{|c|c|c|c|c|c|c|c|c|c|c|c|}
\hline \multicolumn{4}{|c|}{ Large Picoides spp. C } & \multirow{2}{*}{$\frac{\mathrm{D}}{\begin{array}{c}\text { D. fusc- } \\
\text { escens }\end{array}}$} & \multicolumn{2}{|c|}{ Asian spp. E } & \multicolumn{3}{|c|}{ Asian spp. F } & \multicolumn{2}{|c|}{ 3-Toed spp. G } \\
\hline $\begin{array}{l}\text { P. albo- } \\
\text { larvatus }\end{array}$ & $\begin{array}{l}\text { P. strick- } \\
\text { landi }\end{array}$ & $\begin{array}{c}\text { P. villo- } \\
\text { sus }\end{array}$ & $\begin{array}{l}P . \text { bo- } \\
\text { realis }\end{array}$ & & $\begin{array}{l}\text { P. leuco- } \\
\text { tos }\end{array}$ & $\begin{array}{c}P . \\
\text { major }\end{array}$ & $\begin{array}{l}\text { P. cani- } \\
\text { capillus }\end{array}$ & $\begin{array}{l}\text { P. macu- } \\
\text { latus }\end{array}$ & $\begin{array}{c}P . \\
k i z u k i\end{array}$ & $\begin{array}{c}\text { P. arc- } \\
\text { ticus }\end{array}$ & $\begin{array}{l}P . \text { tridac- } \\
\text { tylus }\end{array}$ \\
\hline $\mathrm{C}$ & $\mathrm{C}$ & $\mathrm{C}$ & $\mathrm{C}$ & $\mathrm{D}$ & E & E & $\mathrm{F}$ & $\mathrm{F}$ & $\mathrm{F}$ & G & G \\
\hline $\mathrm{C}$ & $\mathrm{C}$ & $\mathrm{C}$ & $\mathrm{C}$ & $\mathrm{D}$ & & $\mathrm{E}$ & $\mathrm{F}$ & $\mathrm{F}$ & $\mathrm{F}$ & & \\
\hline $\mathrm{C}$ & $\mathrm{C}$ & $\mathrm{C}$ & $\mathrm{C}$ & $\mathrm{D}$ & $\begin{array}{l}\text { E } \\
\text { E }\end{array}$ & E & $\mathrm{F}$ & $\mathrm{F}$ & $\mathrm{F}$ & $\begin{array}{l}\text { G } \\
\text { G }\end{array}$ & $\begin{array}{c}\mathrm{G} \\
\mathrm{G}\end{array}$ \\
\hline $\mathrm{C}$ & $\mathrm{C}$ & $\mathrm{C}$ & $\mathrm{C}$ & $\mathrm{D}$ & $\mathrm{E}$ & $\mathrm{E}$ & $\mathrm{F}$ & $\mathrm{F}$ & $\mathrm{F}$ & G & G \\
\hline $\mathrm{C}$ & $\mathrm{C}$ & $\mathrm{C}$ & $\mathrm{C}$ & $\mathrm{D}$ & $\mathrm{E}$ & $\mathrm{E}$ & $\mathrm{F}$ & $\mathrm{F}$ & $\mathrm{F}$ & G & G \\
\hline $\mathrm{C}$ & $\mathrm{C}$ & & $\mathrm{C}$ & $\mathrm{D}$ & E & $\mathrm{E}$ & $\mathrm{F}$ & $\mathrm{F}$ & $\mathrm{F}$ & G & \\
\hline & & $\mathrm{C}$ & & & & & & & & & G \\
\hline $\mathrm{C}$ & $\mathrm{C}$ & $\mathrm{C}$ & & & E & E & $\mathrm{F}$ & & $\bar{F}$ & G & \\
\hline $\mathrm{C}$ & $\mathrm{C}$ & $\mathrm{C}$ & $\mathrm{C}$ & $\begin{array}{l}\mathrm{D} \\
\mathrm{D}\end{array}$ & E & E & $\mathrm{F}$ & $\begin{array}{l}F \\
F\end{array}$ & $\mathrm{~F}$ & $\mathrm{G}$ & G \\
\hline $\mathrm{C}$ & $\mathrm{C}$ & $\mathrm{C}$ & $\mathrm{C}$ & $\mathrm{D}$ & E & E & $\mathrm{F}$ & $\mathrm{F}$ & $\mathrm{F}$ & $\mathrm{G}$ & $\mathrm{G}$ \\
\hline $\mathrm{C}$ & $\mathrm{C}$ & $\mathrm{C}$ & $\mathrm{C}$ & $\mathrm{E}$ & E & E & $\mathrm{F}$ & $\mathrm{F}$ & $\mathrm{F}$ & G & G \\
\hline & & $\mathrm{C}$ & & $\mathrm{D}$ & E & & & F & & & G \\
\hline & $\mathrm{C}$ & & $\bar{C}$ & & & E & $\mathrm{F}$ & & $\mathrm{F}$ & & \\
\hline C & & & & & & & & & & $\mathrm{G}$ & \\
\hline $\mathrm{C}$ & $\mathrm{C}$ & C & $\mathrm{C}$ & $\mathrm{D}$ & E & E & $\mathrm{F}$ & $\mathrm{F}$ & $\mathrm{F}$ & G & $\mathrm{G}$ \\
\hline $\mathrm{C}$ & C & C & $\mathrm{C}$ & $\mathrm{D}$ & E & E & $\mathrm{F}$ & F & $\mathrm{F}$ & G & G \\
\hline $\mathrm{C}$ & C & C & $\mathrm{C}$ & $\mathrm{D}$ & E & E & $\mathrm{F}$ & ? & $\mathrm{F}$ & $\mathrm{G}$ & $\mathrm{G}$ \\
\hline $\mathrm{C}$ & $\mathrm{C}$ & C & C & D & E & E & $\mathrm{F}$ & $?$ & $\mathrm{~F}$ & $\mathrm{G}$ & G \\
\hline C & $\mathrm{C}$ & $\mathrm{C}$ & C & $\mathrm{D}$ & E & E & F & $?$ & $\mathrm{~F}$ & $\mathrm{G}$ & G \\
\hline $\mathrm{C}$ & $\mathrm{C}$ & $\mathrm{C}$ & $\mathrm{C}$ & $\mathrm{D}$ & E & E & F & F & F & $\mathrm{G}$ & $\mathrm{G}$ \\
\hline $\mathrm{C}$ & $\mathrm{C}$ & C & $\mathrm{C}$ & D & E & E & $\mathrm{F}$ & F & $\mathrm{F}$ & G & G \\
\hline $\mathrm{C}$ & $\mathrm{C}$ & $\mathrm{C}$ & $\mathrm{C}$ & D & E & E & $\mathrm{F}$ & $\mathrm{F}$ & $\mathrm{F}$ & $\mathrm{G}$ & G \\
\hline
\end{tabular}

c Other potentially nonhomologous characters in which ancestral characters states could not be fully resolved throughout the species phylogeny. 